\title{
Biology and Ecology of the El Convento Cave-Spring System (Puerto-Rico)
}

\author{
by
}

Brother G. NICHOLAS*

\section{INTRODUCTION}

The El Convento Cave-Spring System is located in a gorge known as the Quebrada de Los Cedros, a tributary of the Rio Macana, approximately $20 \mathrm{~km}$ west of Ponce in southwestern Puerto Rico. Beck (1974) has described in detail the physical setting and general geology of the system. All references to passages and collecting sites are based on his study. I wish to acknowledge the assistance of Barry Beck, F. L. Miller, Francis McKinney and Peter Pelligreno for transportation and collecting at the site in March, 1973.

\section{FLORA}

The El Convento Cave-Spring System has developed in an area that now is the most arid in all of Puerto Rico. The resulting xerophytic nature of the vegetation is in contrast to the mesophytic forests characteristic of the karst terrain of northwestern Puerto Rico. The general absence of soil plus the absorbent qualities of the underlying Juana Diaz limestone produces a stunted floral growth, comprising a mainly xerophytic scrub vegetation. On the hills and plains surrounding the upper gorge of the Quebrada de Los Cedros, the dominant plant type is the bucida tree, Bucida buceras. However, the gorge itself represents an abrupt transition to an environment with a higher rate of relative humidity but also with much less direct sunlight. Thus, the floral relationships of the Quebrada gorge seem somewhat anomalous in comparison with the dry hills of the Guayanilla area.

Bucida buceras and Bursera simaruba are the dominant trees, but with a taller and more slender configuration than seen outside the narrow confines of the gorge. The llume palm, Gaussia attenuata, is also common. Its presence is not unexpected since it is also typical of the karst belt along the north coast. Its elongate form is peculiarly adapted to the gorge. Shorter trees present include Amyris elemifera and several species of Ficus, the most predominant being F. laevigata. Although the walls of the gorge are almost completely perpendicular to the floor, both Eugenia rhombea and Clusia rosea can be seen growing on isolated ledges. The long aerial roots of these shrubs are interlaced with the lianas Serjania polyphylla and Stigmaphyllon lingulatum. The lianas, aerial roots and dense Ficus branches

\footnotetext{
* La Salle College, Philadelphia, Pa. 19141
} 
intertwine to partially obliterate from view the underlying limestone in the deeper regions of the upper gorge.

The ubiquitous epiphyte Tillansia recurvata (more commonly seen festooning utility wires throughout the islands) cover many of the upper branches of $B$. buceras and B. simaruba. Other epiphytes present are Dendropogon usneoides, Anthurium acaule and Philodendron krebsii, the latter quite common on the exposed ledges of rock. Under breakdown near the stream that flows from the Ojo De Agua Passage into La Rendija Opening at the upper end of Quebrada De Los Cedros, are isolated clumps of the fern Polypodium phyllitidis. Farther down the gorge are to be found plants more indicative of the low humidity: the cacti Cephalocereus Royenli and Leptocereus quadricostatus, plus the spiny maguey, Agave americana. Throughout the gorge can be seen the bromeliad Pitcairnia angustifolia.

\section{FAUNA}

There is no true distinctive cave fauna in the El Convento system (or for all of Puerto Rico) since practically all species collected in the subterranean environment represent forms either common in an epigean environment or closely related to such forms. The numerous entrances to the El Convento system, its comparatively short length, and the periodic flooding action of the stream, all combine to reduce the isolation required for the development of troglobites. Nevertheless, the cave system is of significance because of the high concentration of several species, and the rich nutrient substrate present in the form of bat guano. While this is in general true of all caves in tropical latitudes, the El Convento system is distinctive in having such a rich fauna while isolated from any nearby cave systems. The deposit of guano in the Ojo De Agua Passages is drier and more compact than in the rest of the system. The remainder of the system has few dry ledges accessible for collecting purposes. Thus, specimens were not collected from the higher walks and ceilings.

INSECTA

\section{ARTHROPODA}

Orthoptera

Blattidae

Aspiduchus cavernicola. This large cockroach seems particularly abundant near the lower entrance and has been noted from many Puerto Rican caves (Rhen, 1951; Nicholas, 1966). It feeds on bat guano, dead bats and other insects in the cave.

Gryllidae

Amphiacusta annulipes. This cave cricket was seen throughout the cave, although never in the large population common to some other caves in Puerto Rico. In the Aguas Buenas and Rio Camuy System roots containing several hundred individuals have been found in drier sections of the twilight zone. In all probability individual $A$. annulipes leave the cave to feed. 
Coleoptera

Leiodidae

Propotomaphaginus puertoricensis. This reddish brown beetle was found in abundance in and near the deposits of bat guano. Peck (1970) has previously reported this species from four caves along the North Coast and center of the island (Aguas Buenas) as well as from forest collections. This is the first record from the South Coast, but this species undoubtedly has a cosmopolitan distribution throughout Puerto Rico.

\section{ARACHNIDA}

Amblypygi

Tarantulidae

Tarantula fuscimana. The guava, or tailless whip scorpion, was collected from a few isolated crevices. Since these crevices would normally be flooded during times of high water, the population density is probably higher in the upper reaches of the cave. Common to most Puerto Rican caves, it is a troglophile found only in dark humid environments.

Aranea

Argiopidae

Nesticidae

Leucauge argyra. A common spider, frequently found in and slightly beyond the twilight zone. Four specimens were collected in the El Convento System.

\section{CRUSTACEA}

Amphipoda

Gammaridae

Parawecklia sp. A yet unidentified depigmented amphipod was collected in three pools. This may be related to a species described by Holsinger and Decapoda

Peck (1968) from the Empalme Cave of the Rio Camuy system.

\section{Palaemonidae}

Macrobrachium carcinus. An extremely common shrimp found in practically all the pools throughout the system. The abundant food supply in the form of dead bats, insects and material washed in from the surface is reflected in the population density, which seems unaffected by periodic collecting. It has been noted in numerous caves of the Caribbean (Chase and Hobbs, 1969).

Pseudothelphusidae

Epilobocera sinuatifrons. This land crab is found frequently in and near accumulations of bat guano, into which it burrows. As in the case of Macrobrachium carcinus the abundant food supply has resulted in numerous large specimens measuring up to $85 \mathrm{~mm}$ in carapace length. This crab has been seen throughout the Rio Camuy and Aguas Buenas Systems, but never in such large numbers. 


\section{DIPLOPODA \\ Monocheta \\ Stemmiulidae \\ Stemmiulus compressus \\ Polydesmida \\ Stylodesmidae \\ Lophodesmus bituberculatus. This species had previously been collected by Stewart Peck in the Cueva Pajita near Lares.}

\section{GASTROPODA \\ Pulmonata \\ Camaenidae \\ Caracolus caracola \\ Polyodontes lima \\ Bulimulidae}

Bulimulus guadalupensis. All the species of snail collected are common surface species (Aguayo, 1966). They can readily be washed into the cave.

\section{REPTILIA}

\section{CHORDATA}

Sauria

Gekkonidae

Sphaerodactylus macrolepis. Common to all parts of Puerto Rico. These geckos were sighted in the gorge but may occasionally enter the twilight zone, since they have been sighted in this zone in other caves.

MAMMALIA

Chiroptera

Phyllostomidae

Brachyphylla cavernarum. It is difficult to estimate the bat population in the El Convento system because of high ceilings, many passages partially filled with water, and the high rate of activity displayed by bats in this system. The accumulation of fresh guano indicates a large population. From a visual inspection of those roosts that can be seen at close range, $B$. cavernarum would not seem to be the most abundant species. Six dead adult specimens were collected and many more seen floating in pools. The cause of this mortality could not be determined, although others visiting the cave have reported a similar situation. This species has been found in many other Puerto Rican caves (Anthony, 1925; Nicholas, 1966).

Artebius jamaicensis. The Jamaican fruit-eating bat is the most common mammal in the El Convento system. It predominates in both the Ojo De Agua Passages as well as the main portion of the cave. This species is widespread throughout Puerto Rico and the whole Caribbean area. The dense invertebrate population is without doubt attributable to the guano 
deposited by this bat. At best, one can only give an order to magnitude estimate of its population in the cave system. "Thousands" there probably are.

It is of more than passing interest to note that the water flowing through the heavy concentration of guano and dead bats flows from the cave into a valley from which ground water is being pumped.

\section{ABSTRACT}

The El Convento Cave-Spring System is located at the head of the Quebrada de Los Cedros, approximately $20 \mathrm{~km}$. west of Ponce, southwestern Puerto Rico. Although situated in an arid environment, the gorge receives sufficient moisture from the cave-spring system to support an abundant flora, with Bucida buceras and Bursera simaruba as the dominant trees. The cave is frequently flooded and possesses a rich nutrient substrate in the form of bat guano. Numerous orthopterans (Aspiduchus cavernicola and Amphiacusta annulipes), decapoda (Macrobrachium carcinus and Epilobocera sinuatifrons), and chiroptera (Brachyphylla cavernarum and Artebius jamaicensis) are present. In addition, approximately a dozen other species of invertebrates are found in lesser abundance throughout the system. None of the forms collected demonstrated specific cavernicolous adaptations. Because of the numerous entrances and frequent flooding the possibility of the presence of troglobites is minimal.

\section{RESUMEN}

El Sistema de Cuevas y Fuentas el Convento está situado a la cabeza de la Quebrada de los Cedros, a unos veinte kilómetros al oeste de Ponce en el suroeste de Puerto Rico. Aunque está en un ambiente árido, el desfiladero recibe suficiente humedad de la sistema de cuevas y fuentes para permitir una flora abundante en que predominan los arboles Bucida buceras y Bursera simaruba. Con frecuencia la cueva gueda inundada; además hay un rico substrato nutrivo de guano de murcielagos. Numerous orthopterans (Aspiduchus cavernicola y Amphiacusta annulipes), decapoda (Macrobrachium carcinus y Epilobocera sinuatifrons), y chiroptera (Brachyphylla cavernarum y Artebius jamaicensis), se encuentran. Ademas, aproximadamente una docena de otros invertebrados de menor importancia se hallan a lo largo del sistema. No demuestran especificas adaptaciones cavernicolas ningunas de las especies de invertebrados recogidos. Como resultado de las muchas entradas y las inundaciones frecuentes, es minima la posibilidad de la presencia de troglobitas.

\section{REFERENCES}

AGUAYO, CAROLS G., 1966 - Una lista de los Moluscos terrestres y fluviales de Puerto Rico. Stahlia, 5:1-17. 
ANTHONY, H. E. 1925 - Mammals of Puerto Rico, living and extinct Chiroptera and Insectivora. Scientific Survey of Puerto Rico and the Virgin Islands, 9 (1):1-96. Publ. New York Academy of Science.

BECK, BARRY F. 1974 - Geology and Hydrology of the El Convento Cave-Spring System, Southwestern Puerto Rico. Int. J. Speleol. 6: 93-107.

CHASE, FENNER A. Jr. and HORTON H. HOBBS, Jr. 1969 - The freshwater and terrestrial decapod crustaceans of the West Indies with special reference to Dominica. Bull U.S. Nat. Mus., 292:1-258.

HOLSINGER, JOHN R. and STEWART B. PECK 1968 - A new genus and species of subterranean amphipod (Gammaridae) from Puerto Rico with notes on its ecology, evolution and relationship to other Caribbean amphipods. Crustaceana, 15 (3): 249-262.

NICHOLAS, BROTHER G. 1968 - Discovery at the Rio Camuy Puerto Rico. In: National Geographic Society Research Reports. 1963 Projects, Washington. pp. 115-126.

PECK, STEWART B. 1970 - The Catopinae (Coleoptera: Leiodidae) of Puerto Rico. Psyche, $77(2): 237-242$.

REHN, J. W. H. 1951 - The genus Aspiduchus (Orthoptera: Blattidae: Blaberinae.) Notula Naturae, 231:1-7. 